\title{
PENERAPAN MODEL PEMBELAJARAN APTITUDE TREATMENT INTERACTION (ATI) UNTUK MENINGKATKAN KEMAMPUAN PEMAHAMAN KONSEP MATEMATIS DITINJAU DARI KEMANDIRIAN BELAJAR PESERTA DIDIK
}

\author{
Himelda Dewi ${ }^{1}$, Nanang Supriadi ${ }^{2}$, Rizki Wahyu Yunian Putra ${ }^{3}$ \\ Universitas Islam Negeri Raden Intan Lampung ${ }^{1,2,3}$ \\ pos-el : Himeldadewi95@gmail.com ${ }^{1}, \underline{\text { Nanangsupriadi@ radenintan.ac.id }}{ }^{2}$, \\ Rizkiwahyuyp@radenintan.ac.id ${ }^{3}$
}

\begin{abstract}
ABSTRAK
Kemampuan pemahaman konsep matematis menjadi salah satu komponen yang sangat penting agar bisa dikuasai pengembangannya. Dari hasil pra riset menunjukkan masih rendahnya kemampuan pemahaman konsep matematis peserta didik MTS ANNUR Karang Rejo, ditunjukkan dengan hasil ujian peserta didik pada kemampuan pemahaman konsep matematis tahun ajaran 2019/2020 hanya sebanyak 22 dari 60 peserta didik yang mendapat nilai diatas KKM. Peneliti tertarik untuk menerapkan model pembelajaran aptitude treatment interaction (ATI). Tujuan penelitian ini adalah untuk mengetahui pengaruh model pembelajaran aptitude treathment interaction (ATI) pada peserta didik sebagai upaya untuk meningkatkan kemampuan pada pemahaman konsep matematis. Quasy Eksperimental merupakan jenis penelitian yang diterapkan pada penelitian ini. Instrumen yang digunakan untuk mengumpulkan data adalah tes kemampuan pemahaman konsep matematis. Analisis data penelitian ini adalah analisis variansi dua jalan dengan sel tak sama. Berdasarkan hasil penelitian dapat disimpulkan bahwa : 1) terdapat pengaruh penerapan model pembelajaran aptitude trethment interaction (ATI) dibandingkan dengan pembelajaran konvensional terhadap peningkatan kemampuan pemahaman konsep matematis peserta didik, 2) terdapat pengaruh pada peserta didik dengan memiliki kemandirian belajar tinggi, sedang, dan rendah terhadap adanya peningkatan kemampuan pemahaman konsep matematis, 3) tidak terdapat pengaruh interaksi antara model pembelajaran dan kemandirian belajar untuk meningkatkan kemampuan pemahaman konsep matematis peserta didik.
\end{abstract}

Kata kunci : pemahaman konsep matematis, kemandirian belajar, Aptitude Treatment Interaction

\begin{abstract}
The ability to understand mathematical concepts is one important component that must be mastered and developed. The result of the pre-study show that the ability to understandmathematical concepts of students of MTS ANNUR Karang Rejo is still low, this can be seen from the resultsof the ability to understand mathematical concepts of students in the academic year 2019/2020 obtained the above values (KKM) with a value of $\geq 70$ of 22 from 60 students. Researchers are interested in applying the learning model aptitude treatment interaction (ATI). The purpose of this study was to determine the effect of the aptitude treatment interaction (ATI) learning model to improve the ability to understand mathematical concepts in terms of students learning independence. This researchis a type of research Quasy Experimental Design. The instrument used to collect data is a test of the ability to understand mathematical concepts. Analysis of the data of this research is the analysis of variance of two paths with unequal cells. Based on the results of the study it can be concluded that: 1) there is an effect of the application of the learning model aptitude treatment interaction (ATI) to improve the ability to understand mathematical concepts compared to conventional learning, 2) there is an effect of increasing the ability to understand mathematical concepts that have high, medium, and low learning independence. 3) there is no interaction effect between the learning
\end{abstract}


model and learning independence to improve students' mathematical concept understanding abilities.

Keywords : mathematical concepts understanding, learning independence, Aptitude Treatment Interaction

\section{PENDAHULUAN}

Seiring dengan perkembangan ilmu pengetahuan dan teknologi serta pesatnya globalisasi memerlukan manusia-manusia yang memiliki kemampuan yang berkualitas. Karena itulah maka dalam penciptaan sumber daya berkualitas maka serta kaitannya dengan dunia pendidikan. Pendidikan menjadi cara utama dalam menciptakan individu yang memiliki kualitas. Berkaitan dengan pendikan maka tak dapat lepas dari unsur pendidik yang mampu menjadikan diri seseorang menjadi berkembang. Dengan demikian maka adanya tantangan hidup karena perkembangan teknologi yang muncul dalam kehidupan sehari-hari akan dapat dihadapi. Pendidikan dalam kehidupan sehari-hari sangatlah vital. Sebagaimana yang diamanatkan oleh Undang-Undang bahwa setiap penduduk berhak untuk mendapatkan pendidikan yang layak (Nanang \& Damayanti, 2016).

Matematika menjadi salah satu ilmu dasar yang tidak hanya memiliki peranan penting dalam kehidupan sehari-hari melainkan juga dalam perkembangan teknologi. Meskipun demikian, matematika masih dianggap sebagai momok yang menakutkan karena bukan merupakan mata pelajaran yang dianggap mudah khususnya bagi beberapa peserta didik, sebab saat mendengar kata matematika maka yang akan muncul dipikiran adalah angka dan hitung-hitungan angka yang sifatnya sulit dan termasuk kedalam ilmu yang sukar dikuasai, membosankan, sehingga akan menyebabkan para peserta didik menderita stres (Putra, 2015). Berdasarkan atas tujuan utama dari pemberian pengajaran matematika di sekolah, pemahaman terhadap konsep matematis adalah salah satu dari beberapa kemampuan yang memang harus diajarkan. Gagane, Briggs dan Wargner (Karwono \& Mularsih, 2017) berpendapat bahwa serangkaian kegiatan yang dirancang bagi peserta didik dalam proses pembelajaran ialah makna dari pembelajaran itu sendiri dengan dicirikan pada inisiasi, pemberian fasilitas dan juga adanya peningkatan kemampuan pada peserta, lain halnya dengan beberapa komponen yang harus ada dalam proses seperti tujuan, materi, kegiatan, dan evaluasi pembelajaran.

Kemampuan pemahaman konsep dasar matematika siswa di sekolah sangat diperlukan agar pembelajaran matematika dapat bermakna yang dapat membuat munculnya sikap saling menghargai dalam diri seorang siswa. Selain itu kegunaan lain dari matematika dalam kehidupan adalah memunculkan sikap rasa ingin tau yang tinggi, menarik perhatian serta minat sehingga para siswa akan memiliki sikap percaya diri dalam menyelesaikan segala permasalahan dan persoalan yang berkaitan dengan matematika.

Soinbala, \& Mulyatna (2019) dalam penelitiannya menyatakan bahwa soal mengenai pemahaman 
konsep masih sulit diselesaikan oleh peserta didik penyebabnya tidak lain adalah karena kurangnya instrumen dalam memahami konsep matematis yang dialami oleh para peserta didik. Instrumen pemahaman konsep yang digunakan oleh peneliti dalam penelitian ini adalah berupa konsep pembelajaran berbantuan Geogebra (Pratiwi, 2016).

Penelitian yang dilakukan oleh Fitri \& Utomo (2013) yang berjudul menyimpulkan bahwa nilai ujian tengah semester peserta didik masih sangat kurang. Dari seluruh peserta didik yang berasal dari kelas VII hanya terdapat $24 \%$ peserta didik yang dapat mencapai kriteria ketuntasan minimal atau KKM 79. Ini menunjukan bahwa masih banyak peserta didik kurang paham benar terhadap konsep dan materi yang dipelajari, sehimgga pada saat diberikan soal dengan sedikit variasi masih mengalami kesulitan. Rendahnya kemampuan pemahaman konsep matematis juga ditemukan di MTS AN NUR Lampung Utara seperti pada tabel 1.1 :

Tabel 1. Hasil Nilai Pra-Penelitian

Kemampuan Pemahaman Konsep Matematis Kelas MTS ANNUR Lampung Utara

\begin{tabular}{|c|c|c|c|c|}
\hline \multirow{2}{*}{$\begin{array}{c}\text { Tahun } \\
\text { Pelajaran }\end{array}$} & \multirow{2}{*}{ Kelas } & \multicolumn{2}{|c|}{ Nilai } & \multirow{2}{*}{ Jumlah } \\
\cline { 3 - 4 } & & $<70$ & $\geq 70$ & \\
\hline $2019 / 2020$ & VII A & 21 & 9 & 30 \\
\hline $2019 / 2020$ & VII B & 23 & 7 & 30 \\
\hline \multicolumn{2}{|c|}{ Jumlah } & 44 & 16 & 60 \\
\hline
\end{tabular}

Berdasarkan data di atas peserta didik yang memperoleh hasil belajar di atas KKM ada 16 dari 60 orang peserta didik, sedangkan yang memperoleh hasil belajar di bawh KKM ada 44 dari 60 orang peserta didik. Disajikan dalam grafik sebagai berikut:

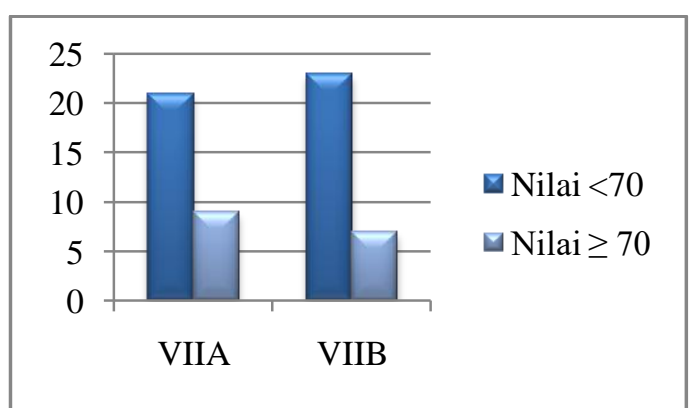

Gambar 1. Grafik Nilai Pra-Penelitian Kemampuan Pemahaman Konsep Matematis

Berdasarkan nilai tersebut dapat dikatakan bahwa kemampuan pemahaman konsep matematis peserta didik masih tergolong rendah. Hal ini terjadi karena selama ini peserta didik hanya mencatat materi tanpa dibaca dan dipahami kembali, menghafal rumus, serta kurang berlatih soal dengan soal yang bervariasi. Banyak peserta didik yang kesulitan mengerjakan soal uraian pemahaman konsep pada materi segitiga yang terlihat dari jawaban salah satu peserta didik yang terlihat dari gambar berikut ini:

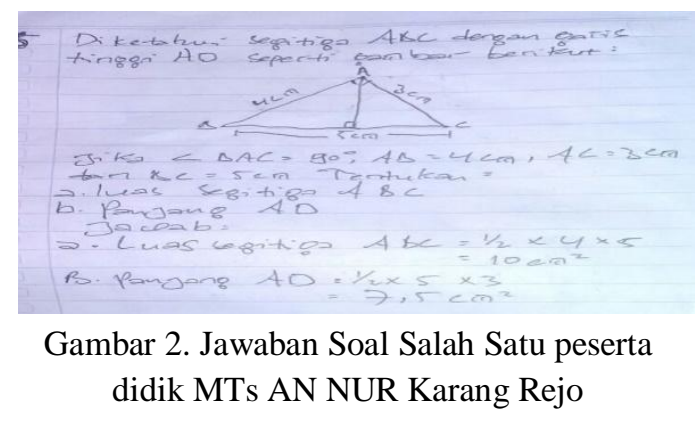

Berdasarkan jawaban peserta didik bahwa luas segitiga $\mathrm{ABC}$ dihitung dengan melihat $\mathrm{AB}$ sebagai alas dan $\mathrm{BC}$ sebagai tinggi. Seharusnya segitiga $\mathrm{ABC}$ dihitung dengan melihat $\mathrm{AB}$ sebagai alas dan AC sebagai tinggi. Sedangkan pada soal nomor 5.b peserta didik belum dapat menjawab pertanyaan dengan baik telihat dari jawaban peserta didik yang salah dalam memasukkan rumus panjang $\mathrm{AD}$. Seharusnya $\mathrm{AD}$ 
dihitung dengan memasukkan hasil luasan $\mathrm{ABC}$ dibagi setengah dikali $\mathrm{BC}$ sebagai alas.

Penelitian yang dilakukan oleh Farida (2015) mengatakan bahwa dalam proses pembelajaran masih melakukan pembelajaran yang bersifat ekspositori atau yang berpusat pada guru. Peserta didik kurang memiliki kepercayaan diri untuk mengkomunikasikan ide dan pemahaman yang dimiliki karena takut salah dan ditertawakan teman.Hal ini membuat guru merasa kesulitan untuk mengetahui kemampuan peserta didik dalam memahami konsep dan mteri yang telah disampaikan. Keadaan ini sangat memperlihatkan bahwa kemampuan pemahaman konsep peserta masih rendah.

Perhatian yang serius diperlukan dalam upaya menjadikan adanya peningkatan terhadap pemahaman siswa pada pemahaman terhadap konsep matematis. Sehingga solusi dari hal ini adalah tentu adanya variasi dalam pembelajaran metode belajar bagi para peserta didik. Model pembelajaran ini berpusat pada peserta didik sehingga peserta didik benar-benar terlibat secara aktif dalam proses pembelajaran. Adanya faktor dari luar sangat memberikan pengaruh terhadap terjadinya peningkatan pada pemahaman peserta didik terhadap konsep matematis. Solo dan Tirtahardja berpendapat, kemampuan sendirilah, pilih sendiri dan tanggung jawab belajar yang mendorong timbulnya kemandirian belajar pada diri peserta didik (Panjaitan, 2013).

Kemandirian belajar peserta didik memberikan kontribusi signifikan terhadap hasil belajar para peserta didik. Peserta didik yang memiliki kemandiriaan belajar yang positif akan mampu bersikap pro aktif pada saat berjalannya aktivitas pembelajaran. Hal ini akan memotivasi diri para peserta didik untuk mampu belajar secara mandiri dan tidak mengandalkan orang lain. Sebaliknya pada peserta didik yang memiliki tingkat kemandirian belajar rendah maka akan cenderung pasif dan tidak proaktif. Mereka hanya akan belajar saat diperintah saja sebab tidak ada jiwa kemandirian dalam diri para peserta didik. Menurut Slavin, seorang yang memiliki kemandirian belajar yang tinggi juga akan memiliki tingkat kepercayaan diri yang tinggi. Dengan hal tersebut maka akan memicu timbulnya rasa keingintahuan yang tinggi (Egok, 2016). Kemandirian belajar sangat dibutuhkan dalam proses pembelajaran. Ini dikarenakan dengan memiliki kemandirian belajar yang tinggi, maka siswa akan memiliki rasa ingin tahu yang besar untuk memahami permasalahan yang ada dan mendorong siswa tersebut untuk mencari informasi secara luas serta mendalam dengan inisiatif sendiri. Selain itu, siswa juga menjadi memiliki kesadaran akan tanggung jawab terhadap tugas-tugas belajar sehingga berdampak pada hasil belajar yang diperoleh (Astuti, Susilo, \& Sari, 2018).

Terdapat banyak model pembelajaran yang dapat digunakanoleh guru dalam proses pembelajaran salah satunya adalah model pembelajaran ATI pada pengajaran klasikal guru mengajar sejumlah peserta didik diasumsikan minatnya, kepentingannya, kecakapannya dan kecepatan belajarnya relatif sama. Sementara itu, keadaan kelas secara umum dalam hal ini adalah bakat (Aptitude) yang dimiliki oleh para 
peserta didik sangatlah heterogen atau beragam dalam pembelajaran konvensional, sehingga bakat (Aptitude) para peserta didik dapat dikatakan tersebar secara normal. Menurut Ruseffendi (1979) menyatakan bahwa dalam pembelajaran konvensional atau tradisional tidak dapat memenuhi kemampuan para peserta didik oleh karena itu maka bakat yang dimiliki oleh para peserta didik tidak akan dapat dikeluarkan secara optimal pada saat berada di kelas. Diharapkan dengan adanya model pembelajaran ATI dapat menjadi solusi dalam mengatasi kesulitan belajar matematika yang dialamai peserta didik Indonesia. Model pembelajaran ATI berasumsi bahwa optimalisasi prestasi akademik atau hasil belajar akan tercipta bilamana perlakuan-perlakuan dalam pembelajaran di sesuaikan sedemikian rupa dengan perbedaan kemampuan. Penerapan model pembelajaran ATI dapat berpengaruh dalam meningkatkan kemampuan pemahaman konsep matematis peserta didik.

Berdasarkan studi pendahuluan, penelitian ini berupaya untuk memberikan solusi terkait dengan penemuan metode yang dapat dipakai dalam pembelajaran yaitu dengan Penerapan Model Belajar Aptitude Treathment Interaction (ATI) untuk Meningkatkan Kemampuan Pemahaman Konsep Matematis Ditinjau dari Kemandirian Belajar peserta didik. Penelitian ini bertujuan untuk: 1) Mengetahui kemampuan pemahaman konsep matematis peserta didik yang memperoleh model pembelajaran aptitude treatment interaction (ATI) dibandingkan peserta didik yang memperoleh model pembelajaran konvensional, 2) mengetahui perbedaan kemampuan pemahaman konsep matematis yang ditinjau dari kemandirian belajar peserta didik berdasarkan tingkatan tinggi, sedang dan rendah, dan 3) mengetahui apakah terdapat interaksi antara model pembelajaran dan kemandirian belajar para peserta didik terhadap kemampuan pemahaman konsep matematis.

\section{METODE PENELITIAN}

Dalam penelitian ini metode yang dipakai yakni penelitian eksperimen, dimana penelitian dibuat dengan tujuan agar dapat mencari pengaruh antara penerapan perlakuan tertentu terhadap yang lain pada konsisi yang terkendali. Quansy experimental design sebab dalam penelitian ini terdapat variabel kontrol yang tidak bisa mengontrol variabel luar yang dapat mempengaruhi eksperimen karena tidak difungsikan secara penuh (Sugiyono, 2015). Jenis penelitian ini adalah penelitian kuantitatif.

Rancangan eksperimen dalam penelitian yang dilakukan adalah posstest-only control design. Rancangan pada penelitian ini menggunakan dua kelas eksperimen. Kelompok pertama yaitu kelompok yang mendapat perlakuan pembelajaran matematika dengan menggunakan model pembelajaran Aptitude Treatment Interaction (ATI), kelompok yang kedua adalah peserta didik yang mendapat perlakuan pembelajaran matematika dengan menggunakan model pembelajaran konvensional. Variabel bebas yang digunakan dalam penelitian ini adalah model pembelajaran Aptitude Treatment Interaction (ATI) dan kemandirian 
peserta didik sedangkan Variabel terikat pada penelitian ini adalah kemampuan pemahaman konsep matematis peserta didik.

Populasi dalam penelitian ini adalah seluruh peserta didik kelas VII di MTS ANNUR Karang Rejo yang berjumlah 60 peseta didik. Penelitian ini menggunakan dua kelas yaitu kelas VII A Sebagai kelas kontrol dan VII B sebagai kelas eksperimen, kelas eksperimen sebagai kelas sampel yang diterapkan model pembelajarn Aptitude Trethment Interction, sedangkan kelas kontrol diterapkan sebagai model pembelajaran konvensional. Melalui tes dan kuesioner sebagai teknik pengumpulan data. Analisis data menggunakan Uji Anova Dua Jalur.

\section{HASIL DAN PEMBAHASAN}

Berdasarkan hasil penelitian diperoleh nilai pretest, postest dan $\mathrm{N}$ gain peserta didik. Berikut ini masingmasing analisis data yang dilakukan:

\section{Analisis Data Pretest}

Tabel 2. Deskripsi data Hasil Pretest Kemampuan Pemahaman Konsep Mamtematis

\begin{tabular}{|c|c|c|c|c|c|}
\hline Kelompok & $\bar{x}$ & $\mathrm{M}_{0}$ & $\mathrm{M}_{\mathrm{e}}$ & $\mathrm{X}_{\operatorname{maxs}}$ & $\mathrm{X}_{\min }$ \\
\hline Eksperimen & 51 & 47 & 48 & 81 & 13 \\
\hline Kontrol & 56 & 41 & 56 & 88 & 25 \\
\hline
\end{tabular}

Berdasarkan tabel di atas, nilai hasil tes sebelum proses pembelajaran dengan nilai tertinggi yakni pada kelas ekperimen sebesar 81 dan pada kelas kontrol sebesar 88 , untuk nilai terendah dalam kelas eksperimen ialah sebesar 13 serta 25 untuk kelas kontrol. Nilai 51 merupakan ukuran dari tendensi sentral yang meliputi rataan atau mean pada kelas eksperimen dan sebesar 56 pada kelas kontrol. Kemudian dilakukan pengujian hipotesis terhadap nilai pretest peserta didik, sebagai berikut:

Tabel 3 Hasil Uji Normalitas Pretest

\begin{tabular}{|c|c|c|c|}
\hline Kelompok & $L_{\text {hitung }}$ & $L_{\text {tabel }}$ & Keputusan Uji \\
\hline Eksperimen & 0,112 & 0,159 & $\mathrm{H}_{0}$ Diterima \\
\hline Kontrol & 0,065 & 0,159 & $\mathrm{H}_{0}$ Diterima \\
\hline
\end{tabular}

Berdasarkan hasil uji normalitas Pretest data peserta didik yang disajikan pada tabel di atas, terlihat bahwa taraf signifikansi5\% nilaiL ${ }_{h i t u n g}$ pada setiap kelompok kurang dari $\mathrm{L}_{\text {ta } 9 \text { bel }}$ maka hipotesis nol pada setiap kelompok diterima sehingga dapat disimpulkan data setiap kelompok bersal dari populasi yang berdistribusi normal.

Tabel 4 Hasil Uji Homogenitas Pretest

\begin{tabular}{|c|c|c|c|}
\hline Data & $F_{\text {hitung }}$ & $F_{\text {tabel }}$ & Keputusan Uji \\
\hline Pretest & 1,091 & 1,861 & $\mathrm{H}_{0}$ Diterima \\
\hline
\end{tabular}

$\mathrm{F}_{\text {hitung }}$ pada kelompok nilainya tidak melebihi pada nilaiF $F_{\text {tabel }}$. Dimana nilai hitung Pretest didapatkan hasil perhitungan pada kelas ekperimen dan kontrol sebesar $F_{\text {hitung }}=1,091$ dengan $\mathrm{F}_{\text {tabel }}=1,861$ sehingga $\mathrm{H}_{0}$ diterima. Sehingga dapat ditarik kesimpulan bahwa sampel yang digunakan dalam penelitian ini merupakan sampel yang berasal dari populasi yang homogen.

Tabel 5. Hasil Uji Hipotesis Pretest

Kemampuan Pemahaman Konsep Matematis

\begin{tabular}{|c|c|c|c|}
\hline Data & $\mathrm{t}_{\text {hitung }}$ & $\mathrm{t}_{\text {tabel }}$ & Keputusan \\
\hline Pretest & 1,098 & 2,002 & $\mathrm{H}_{0}$ diterima \\
\hline
\end{tabular}

Dari hasi pretest yang dimiliki oleh para peserta didik pada materi perbandingan ditunjukkan dengan nilai $\mathrm{t}_{\text {hitung }}=1,098<\mathrm{t}_{\text {tabel }}=2,002$ yang artinya signifikan $\propto=0.05$ sehingga $\mathrm{H}_{0}$ diterima maka hal ini menandakan 
adanya kemampuan yang sama baik pada kelas kontol ataupun eksperimen terhadap pemahaman konsep matematis.

\section{Analisis Data Postest}

Tabel 6. Deskripsi Data Hasil Postest

Kemampuan Pemahaman Konsep

Matematis

\begin{tabular}{|c|r|c|c|c|c|}
\hline Kelompok & $\bar{x}$ & $\mathrm{M}_{0}$ & $\mathrm{M}_{\mathrm{e}}$ & $\mathrm{X}_{\operatorname{maxs}}$ & $\mathrm{X}_{\min }$ \\
\hline Eksperimen & 82 & 97 & 83 & 97 & 63 \\
\hline Kontrol & 74 & 66 & 77 & 91 & 53 \\
\hline
\end{tabular}

Berdasarkan tabel di atas menunjukkan bahwa nilai hasil postest dari proses pembelajaran dimana nilai tertinggi yang ada dalam kelas eksperimen adalah sebesar 97 dan untuk kelas kontrol ialah sebesar 91, sedangkan nilai terendah untuk kelas ekperimen adalah sebesar 63 dan kelas kontrol 53. Ukuran tendensi sentral yang meliputi rata-rata kelas (mean) untuk kelas eksperiman sebesar 82 dan kelas kontrol sebesar 74 . Kelas eksperimen memiliki nilai pasttest yang lebih besar dibanding kelas kontrol dengan demikian maka kesimpulan yang dapat diambil adalah adanya kemampuan pemahaman terhadap konsep matematis yang lebih besar pada kelas eksperimen dibanding kelas kontrol. Kemudian dilakukan pengujian normalitas terhadap nilai postest peserta didik, sebagai berikut:

Tabel 7. Hasil Uji Normalitas postest

\begin{tabular}{|c|c|c|c|}
\hline Kelompok & $L_{\text {hitung }}$ & $L_{\text {tabel }}$ & Keputusan Uji \\
\hline Eksperimen & 0,107 & 0,159 & $\mathrm{H}_{0}$ Diterima \\
\hline Kontrol & 0,93 & 0,159 & $\mathrm{H}_{0}$ Diterima \\
\hline Tinggi & 0,150 & 0,184 & $\mathrm{H}_{0}$ Diterima \\
\hline Sedang & 0,113 & 0,188 & $\mathrm{H}_{0}$ Diterima \\
\hline Rendah & 0,110 & 0,207 & $\mathrm{H}_{0}$ Diterima \\
\hline
\end{tabular}

Taraf signifikansi 5\% pada data peserta didik didapatkan nilai $L_{h i t u n g}$ pada setiap kelompok hasilnya kurang dari nilai $\mathrm{L}_{\text {tabel }}$ sehingga berdasarkan hal tersebut $\mathrm{H}_{\mathrm{o}}$ diterima. Sehingga kesimpulannya adalah bahwa data dari setiap kelompok berasal dari populasi yang terdistribusi normal.

Tabel 8. Hasil Uji HomogenitasPretest

\begin{tabular}{|c|c|c|c|}
\hline Kelompok & $F_{\text {hitung }}$ & $F_{\text {tabel }}$ & Keputusan Uji \\
\hline $\begin{array}{c}\text { Kontrol, } \\
\text { Eksperimen }\end{array}$ & 1,022 & 1,861 & $\mathrm{H}_{0}$ Diterima \\
\hline $\begin{array}{c}\text { Tinggi, } \\
\text { Sedang, } \\
\text { Rendah }\end{array}$ & 0,2628 & 5,9915 & $\mathrm{H}_{0}$ Diterima \\
\hline
\end{tabular}

Berdasarkan tabel terlihat bahwa $\mathrm{F}_{\text {hitung }}$ kelompok tidak melebihi $\mathrm{F}_{\text {tabel }}$. Data hasil perhitungan Posttest antar kelas eksperimen dan kelas kontrol diperoleh $\mathrm{F}_{\text {hitung }}<\mathrm{F}_{\text {tabel }} \quad(1,022<$ 1,861) sehingga $\mathrm{H}_{0}$ diterima. Dapat disimpulkan bahwa sampel berasal dari populasi yang homogen.

Tabel 9. Hasil Uji Anava Dua Jalan Sel Tak Sama Posttest

\begin{tabular}{|c|c|c|c|}
\hline Sumber & $\mathrm{F}_{\text {hitung }}$ & $\mathrm{F}_{\text {tabel }}$ & Keputusan Uji \\
\hline$(\mathrm{A})$ & 5,700 & 4,020 & $\mathrm{H}_{0}$ Ditolak \\
\hline$(\mathrm{B})$ & 4,997 & 3,168 & $\mathrm{H}_{0}$ Ditolak \\
\hline Interaksi $(\mathrm{AB})$ & 0,305 & 3,168 & $\mathrm{H}_{0}$ Diterima \\
\hline
\end{tabular}

Berdasarkan pada hasil perhitungan analisis data yang telah dilakukan, dimana hasilnya ditunjukkan pada tabel diatas menunjukkan bahwa : $F_{\text {hitung }}=5,700$ dan pada taraf sginifiansi $5 \%$ diperoleh hasil $F_{\text {tabel }}=$ 4,020 maka berdasarkan hasil tersebut menujukkan bahwa $F_{\text {hitung }}>F_{\text {tabel }}$. Hal ini menghasilkan kesimpulan bahwa $H_{O A}$ ditolak yang berarti menunjukkan bahwa terdapat perbedaan peningkatan kemampuan pemahaman konsep matematis pada peserta didik yang diberikan model pembelajaran API dengan peserta didik yang diberikan model pembelajaran konvensional. 
$F_{\text {hitung }}=4,997$ dan taraf signifikansi $5 \%$ diperoleh hasil bahwa nilai $F_{\text {tabel }}=3,16$ sehingga $F_{\text {hitung }}>$ $F_{\text {tabel }}$ yang menunjukkan bahwa $H_{O b}$ ditolak hal ini menujukkan bahwa terdapat perbedaan peningkatan kemampuan pemahaman konsep matematis pada peserta didik dengan kemandirian belajar tinggi, sedang dan juga rendah.

$$
F_{\text {hitung }}=0,305 \text { dan taraf }
$$

signifikansi $5 \%$ maka diperoleh nilai bahwa $F_{\text {tabel }}=3,168$ maka berdasarkan hal tersebut menunjukkan bahwa nilai $F_{\text {hitung }}>F_{\text {tabel }}$ dengan demikian maka $H_{O A B}$ sehingga menunjukkan bahwa tidak terdapat perbedaan antara model pembelajaran ATI terhadap peningkatan kemampuan pemahaman konsep matematis peserta didik. Pengujian uji lanjut anova dengan Scheffe diperoleh hasil sebagai berikut: Tabel 10. Hasil Uji Komparasi Ganda Antar Kolom Posttest

\begin{tabular}{|c|c|c|c|}
\hline Interaksi & $\mathrm{F}_{\text {hitung }}$ & $\mathrm{F}_{\text {tabel }}$ & Kesimpulan \\
\hline$\mu_{1} V S \mu_{2}$ & 10,577 & 6,336 & $\mathrm{H}_{0}$ ditolak \\
\hline$\mu_{1} V S \mu_{3}$ & 4,457 & 6,366 & $\mathrm{H}_{0}$ diterima \\
\hline$\mu_{2} V S \mu_{3}$ & 6,366 & 6,336 & $\mathrm{H}_{0}$ diterima \\
\hline
\end{tabular}

Hasil data perhitungan uji komparasi ganda antar kolom pada masing-masing kemandirian belajar, dengan taraf signifikan 0,05 diperoleh bahwa $\mu_{1} V S \mu_{2}$ menunjukkan bahwa $\mathrm{F}_{\text {hitung }}>\mathrm{F}_{\text {tabel }}$ dengan nilai $\mathrm{F}_{\text {hitung }}=$ 10,577 dan $F_{\text {tabel }}=6,336$, sehingga $\mathrm{H}_{0}$ ditolak maka hal ini menunjukkan bahwa terdapat perbedaan peningkatan pemahaman konsep matematis antara peserta didik yang memiliki kemandirian belajar tinggi dengan peserta didik yang memiliki tingkat kemandirian belajar sedang. $\mu_{1} V S \mu_{3}$ menunjukkan bahwa $\mathrm{F}_{\text {hitung }}>\mathrm{F}_{\text {tabel }}$ dengan nilai $\mathrm{F}_{\text {hitung }}=$ 4,457 dan $F_{\text {tabel }}=6,366$. Sehingga $\mathrm{H}_{0}$ diterima, hal ini menunjukkan bahwa tidak terdapat perbedaan peningkatan pemahaman konsep matematis antara peserta didik yang memiliki kemandirian belajar tinggi dengan peserta didik dengan kemandirian belajar rendah.

$\mu_{2} V S \mu_{3}$ menunjukkan bahwa $\mathrm{F}_{\text {hitung }}>\mathrm{F}_{\text {tabel }}$ dengan nilai $\mathrm{F}_{\text {hitung }}=$ 0,905 dan $F_{\text {tabel }}=6,366$. Sehingga $\mathrm{H}_{0}$ diterima, hal ini menunjukkan bahwa tidak terdapat perbedaan peningkatan pemahaman konsep matematis terhadap peserta didik dengan kemandirian belajar sedang dan peserta didik dengan kemandirian belajar rendah.

\section{Analisis Data N-gain}

Tabel 11. Deskripsi Data Hasil $N$-gain Kemampuan Pemahaman Konsep Matematis

\begin{tabular}{|c|c|c|c|c|}
\hline Kelompok & $\bar{x}$ & $\mathrm{M}_{0}$ & $\mathrm{X}_{\operatorname{mak}}$ & $\mathrm{X}_{\min }$ \\
\hline Eksperimen & 0,61 & 0,71 & 0,95 & 0 \\
& & & & \\
\hline Kontrol & 0,34 & 0,5 & 0,87 & $-0,88$ \\
\hline
\end{tabular}

Berdasarkan tabel di atas dapat dilihat bahwa nilai $N$-gain dengan nilai tertinggi pada kelas eksperimen adalah 0,95 dan kelas kontrol adalah 0,87 sedangkan nilai terendah untuk kelas eksperimen adalah 0 dankelas kontrol 0,87 ukuran tendensi sentral yang meliputi rata-rata (mean) untuk kelas eksperimen sebesar 0,61 dan kelas kontrol sebesar 0,34, sementara untuk nilai tengah kelas eksperimen yitu sebesar 0,71 dan kelas kontrol sebesar 0,42 sedangkan modus pada kelas eksperimen adalah 0,71 dan kelas kontrol adalah 0,5. Dapat disimpulkan 
bahwa data N-Gain kelas eksperimen yang diberi treatment model pembelajaran Aptitude Treathment Interction lebih tinggi dibandingkan dari kelas kontrol yang diberi treatment model pembelajaran konvensional. Kemudian dilakukan pengujian hipotesis terhadap nilai $\mathrm{N}$-gain peserta didik, sebagai berikut:

Tabel 12. Hasil Uji Normalitas $\mathrm{N}$-gain

\begin{tabular}{|c|c|c|c|}
\hline Kelompok & $L_{\text {hitung }}$ & $L_{\text {tabel }}$ & $\begin{array}{c}\text { Keputusan } \\
\text { Uji }\end{array}$ \\
\hline $\begin{array}{c}\text { N-Gain } \\
\text { (Eksperimen) }\end{array}$ & 0,135 & 0,159 & $\mathrm{H}_{0}$ diterima \\
\hline $\begin{array}{c}\text { N-Gain } \\
\text { (Kontrol) }\end{array}$ & 0,113 & 0,159 & $\mathrm{H}_{0}$ diterima \\
\hline $\begin{array}{c}\text { N-Gain } \\
\text { (Tinggi) }\end{array}$ & 0,160 & 0,184 & $\mathrm{H}_{0}$ diterima \\
\hline $\begin{array}{c}\text { N-Gain } \\
\text { (Sedang) }\end{array}$ & 0,127 & 0,188 & $\mathrm{H}_{0}$ diterima \\
\hline $\begin{array}{c}\text { N-Gain } \\
\text { (Rendah) }\end{array}$ & 0,102 & 0,207 & $\mathrm{H}_{0}$ diterima \\
\hline
\end{tabular}

Berdasarkan hasil uji normalitas peserta didik yang terangkum dalam tabel di atas, nampoak bahwa taraf signifikansi $5 \%$ nilai $\mathrm{L}_{\text {hitung }}$ untuk setiap kelompok kurng dari $\mathrm{L}_{\text {tabel }}$, sehingga hipotesis nol untuk setiap kelompok berasal dari populasi yang berdistribusi normal.

Tabel 13. Hasil Uji Homogenitas $N$-gain

\begin{tabular}{|c|c|c|c|}
\hline Kelompok & $F_{\text {hitung }}$ & $F_{\text {tabel }}$ & $\begin{array}{c}\text { Keputusan } \\
\text { Uji }\end{array}$ \\
\hline $\begin{array}{c}\text { N-Gain } \\
\text { (Kontrol, } \\
\text { Eksperimen) }\end{array}$ & 1,31 & 1,86 & $\begin{array}{c}\mathrm{H}_{0} \\
\text { diterima }\end{array}$ \\
\hline $\begin{array}{c}\text { N-Gain } \\
\text { (Tinggi, } \\
\text { Sedang, } \\
\text { Rendah) }\end{array}$ & 0,948 & 5,99 & $\mathrm{H}_{0}$ diterima \\
\hline
\end{tabular}

Berdasarkan hasil uji homogenitas $\mathrm{N}$-gain menunjukkan bahwa $\mathrm{F}_{\text {hitung }}$ tidak melebihi $F_{\text {tabel }}$. Data hasil perhitungan N-Gain kelas eksperimen dan kelas kontrol didapat $\mathrm{F}_{\text {hitung }}=1,31$ dengan $\quad F_{\text {tabel }}=1,86 \quad$ sehingga menunjukkan bahwa $\mathrm{H}_{0}$ diterima. Dapat ditarik kesimpulan bahwa sampel berasal dari populasi yang homogen. Setelah uji persyaratan anova terpenuhi dilakukan pengujian hipotesis $\mathrm{N}$-gain sebagai berikut:

Tabel 14. Hasil Uji Anava Dua Jalan Sel

\begin{tabular}{|c|c|c|l|}
\multicolumn{4}{c}{ Tak Sama $N$-gain } \\
\hline Sumber & $\mathrm{F}_{\text {hitung }}$ & $\mathrm{F}_{\text {tabel }}$ & $\begin{array}{c}\text { Keputusan } \\
\text { Uji }\end{array}$ \\
\hline$(\mathrm{A})$ & 8,374 & 4,020 & $\mathrm{H}_{0}$ Ditolak \\
\hline$(\mathrm{B})$ & 3,187 & 3,168 & $\mathrm{H}_{0}$ Ditolak \\
\hline $\begin{array}{c}\text { Interaksi } \\
(\mathrm{AB})\end{array}$ & 0,095 & 3,168 & $\mathrm{H}_{0}$ Diterima \\
\hline
\end{tabular}

Berdasarkan perhitungan analisis data dapat disimpulkan bahwa $\mathrm{F}_{\text {hitung }}=$ 8,374 dan taraf signifikansi 5\% diperoleh $F_{\text {tabel }}=4,020$ sehingga $\mathrm{F}_{\text {hitung }}>\mathrm{F}_{\text {tabel }}$ yang menunjukkan bahwa $H_{O A}$ ditolak berarti terdapat perbedaan kemampuan pemahaman konsep matematis antara peserta didik yang diberi model pembelajaran ATI dan peserta didik yang diberi pembelajaran konvensional.

$$
\mathrm{F}_{\text {hitung }}=3,187 \text { dan taraf }
$$
signifikansi $5 \%$ diperoleh $\mathrm{F}_{\text {tabel }}=$ 3,168 sehingga $\mathrm{F}_{\text {hitung }}>\mathrm{F}_{\text {tabel }}$ yang menunjukkan bahwa $H_{O b}$ ditolak berarti terdapat perbedaan peningkatan kemampuan pemahaman konsep matematis peserta didik yang memiliki kemandirian belajar tinggi, sedang dan rendah.

$\mathrm{F}_{\text {hitung }}=0,095$ dan taraf signifikansi 5\% diperolah $\mathrm{F}_{\text {tabel }}=3,168$ sehingga $\quad \mathrm{F}_{\text {hitung }}>\mathrm{F}_{\text {tabel }} \quad$ yang menunjukkan bahwa $H_{O A B}$ diterima berarti tidak terdapat interaksi pengaruh antara model pembelajaran ATI terhadap peningkatan kemampuan pemahaman konsep matematis peserta didik. Pengujian uji lanjut anova dengan Scheffe diperoleh hasil sebagai berikut: 
Tabel 15. Hasil Uji komparasi Ganda Antar Kolom $N$-gain

\begin{tabular}{|c|c|c|c|}
\hline Interaksi & $\mathrm{F}_{\text {hitung }}$ & $\mathrm{F}_{\text {tabel }}$ & Kesimpulan \\
\hline$\mu_{1} V S \mu_{2}$ & 7,038 & 6,336 & $\mathrm{H}_{0}$ ditolak \\
\hline$\mu_{1} V S \mu_{3}$ & 1,895 & 6,366 & $\mathrm{H}_{0}$ diterima \\
\hline$\mu_{2} V S \mu_{3}$ & 1,249 & 6,336 & $\mathrm{H}_{0}$ diterima \\
\hline
\end{tabular}

Berdasarkan tabel 15 hasil data perhitungan uji komparasi ganda antar kolom pada masing-masing kemandirian belajar, dengan taraf signifikan 0,05 diperoleh bahwa $\mu_{1} V S \mu_{2}$ menunjukkan bahwa $\mathrm{F}_{\text {hitung }}>$ $\mathrm{F}_{\text {tabel }}$ dengan nilai $\mathrm{F}_{\text {hitung }}=7,038$ dan $\mathrm{F}_{\text {tabel }}=6.336$ maka hal ini menandakan bahwa $\mathrm{H}_{0} \quad$ ditolak, sehingga menunjukkan bahwa terdapat perbedaan peningkatan pemahaman konsep matematis antara peserta didik dengan kemandirian belajar tinggi dan peserta didik dengan kemandirian belajar sedang.

$\mu_{1} V S \mu_{3}$ menunjukkan bahwa $\mathrm{F}_{\text {hitung }}>\mathrm{F}_{\text {tabel }}$ dengan nilai $\mathrm{F}_{\text {hitung }}=$ 1,895 dan $F_{\text {tabel }}=6,336$. Sehingga $\mathrm{H}_{0}$ diterima, berarti tidak terdapat perbedaan peningkatan pemahaman konsep matematis antara peserta didik yang meniliki kemandirian belajar tinggi dengan peserta didik yang memiliki kemandirian rendah.

$\mu_{2} V S \mu_{3}$ menunjukkan bahwa $\mathrm{F}_{\text {hitung }}>\mathrm{F}_{\text {tabel }}$ dengan nilai $\mathrm{F}_{\text {hitung }}=$ 1,249 dan $\mathrm{F}_{\text {tabel }}=6,336$, dengan demikian maka $\mathrm{H}_{0}$ diterima, maka hal tersebut menunjukkan pemahaman konsep matematis pada peseta didik dengan kemampuan belajar rendah dan sedang tidaklah berbeda.

Berdasarkan pada hasil analisis data yang telah dilakukan oleh peneliti, menunjukkan bahwa konsep pembelajaran ATI yang diterapkan pada para peserta didik ternyata memiliki pengaruh terhadap peningkatan pemahaman konsep matematis. Penarikan kesimpulan tersebut didasarkan pada adanya perbedaan nilai kemampuan pemahaman konsep matematis yang diperoleh peserta didik yang ada dalam kelas ekperimen dengan para peserta didik pada kelas kontrol. Indikasi tersebut diperoleh setelah peneliti menerapkan proses pembelajaran ATI pada peserta didik dalam kelas eksperimen dan pembelajaran konvensional pada peserta didik di kelas kontrol, sehingga hasil analisis data yang dapat mendukung hipotesis adalah 1) yang menyatakan bahwa peserta didik yang memperoleh model pembelajaran ATI memiliki peningkatan kemampuan pemahaman konsep matematis lebih baik dari pada peserta didik yang memperoleh model pembelajaran konvensional, 2) tidak terdapat perbedaan yang signifikan antara peserta didik yang memiliki kemandirian belajar tinggi dan sedang. Ini menunjukkan kemandirian belajar pada peserta didik dengan kemandirian belajar tinggi dan sedang tidaklah berbeda.

Penelitian ini juga didasarkan pada penelitian yang telah dilakukan sebelumnya, yaitu penelitian yang dilakukan oleh (Herlina, 2015) dimana pendekatan yang digunakan juga merupakan pembelajaran ATI sebagai alternatif untuk meningkatkan pemahaman konsep matematis bagi para peserta didik. Oleh karena itu,maka bagi para pengajar yang hendak menerapkan konsep pembelajaran ATI dalam pembelaran matematika hendaknya memperhatikan langkah-langkah yang sesuai dan juga sistematis dengan apa 
yang diterapkan dalam proses pembelajran ATI sehingga tidak hanya berdampak pada pengajar namun juga efektif baik peningkatan kompetensi para peserta didik. Hal ini juga merupakan tambahan pengetahuan model pembelajaran lain yang dapat diterapkan oleh para pengajar (Herlina, 2015).

Aptitude Treatment Interaction merupakan sebuah model pembelajaran dimana menggunakan konsep pendekatan yang memiliki sejumlah strategi pembelajaran (Treathment) yang cukup efektif jika digunakan oleh para pengajar sesuai dengan kemampuan masing-masing. Ciri utama dari penerapan model pembelaran ATI adalah dengan memberikan perhatian khusus terhadap setiap perbedaan yang dimiliki oleh para peserta didik, dimana dalam setiap kelompok terdapat perbedaan kemampuan yang dimiiki oleh peserta didik yakni kemampuan tinggi, sedang dan rendah. Aptitude Treatment Interaction berisikan strategi untuk mengelompokkan para peserta didik berdasarkan pada kemampuannya, dan selanjutnya diberikan perlakuan yang berbeda pada setiap kelompok disesuaikan dengan kemampuan para peserta didik dan karakteristik cara belajarnya. Tujuan yang ingin dicapai tidak lain adalah agar tercipta sebuah model pembelejaran yang benar-benar peduli dan sesuai dengan kemampuan atau Aptitude atau pengalaman belajar peserta didik atau juga ketepatan penggunaan metode (threatment).

\section{KESIMPULAN}

Berdasarkan hasil analisis data dan pengujian hipotesis terhadap data penelitian mengenai penerapan model pembelajaran Aptitude Treatmeant Interactions (ATI) untuk meninjau kemandirian belajar peserta didik berdasarkan pada pemahaman terhadap konsep matematis yang ada di kelas VII MTS ANNUR Karang Rejo yang telah dilaksanakan oleh penulis maka dapat ditarik kesimpulan sebagai berikut: (1) Dengan penerapan metode pembelajaran ATI terjadi peningkatan kemampuan terhadap pemahaman konsep matematis peserat didik yang lebih baik dibanding pada peserta didik yang memperoleh model pembelajaran konvensional; (2) Terdapat perbedaan peningkatan kemandirian belajar peserta didik kelompok rendah, sedang dan tinggi pada peserta didik yang memperoleh model pembelajaran Aptitude Treatmeant Interaction (ATI) dengan kelompok peserta didik yang memperoleh model pembelajaran konvensional; (3) Ditinjau dari interaksi antara model pembelajaran dengan katergori Aptitude Treatmeant Interaction (ATI) untuk meningkatkan kemampuan pemahaman konsep matematisnya, disimpulkan bahwa tidak terdapat interaksi antara model pembelajaran dengan kategori Aptitude Treatmeant Interactions (ATI) peserta didik untuk meningkatkan kemampuan pemahaman konsep matematis.

\section{DAFTAR PUSTAKA}

Astuti, D., Susilo, G., \& Sari, T. H. N. I. (2018). Pengaruh Konsentrasi Belajar dan Kemandirian Belajar Terhadap Hasil Belajar Matematika Siswa Kelas XI SMA Negeri 2 Balikpapan Tahun Ajaran 2017/2018. De Fermat: Jurnal Pendidikan Matematika, I(2), 102113. Retrieved from 
http://jurnal.pmat.unibabpn.ac.id/index.php/DEFERMAT/ar ticle/view/25

Egok, A. S. (2017). Kemampuan berpikir kritis dan kemandirian belajar dengan hasil belajar matematika. Jurnal Pendidikan Dasar UNJ, 7(2), 186-199.

Farida, F. (2015). Pengaruh strategi pembelajaran heuristic vee terhadap kemampuan pemahaman konsep dan komunikasi matematis peserta didik. Al-Jabar : Jurnal Pendidikan Matematika, 6(2), 111119.

doi:https://doi.org/10.24042/ajpm. v6i2.22

Fitri, S., \& Utomo, R. B. (2016). Pengaruh model pembelajaran auditory, intellectually, and repetition terhadap kemampuan pemahaman konsep di SMP Pustek Serpong. JURNAL

DuMath, 2(2).

Soinbala, H., \& Mulyatna, F. (2019). Penerapan Strategi Pembelajaran Metakognitif Dalam Meningkatkan Pemahaman Konsep Matematika. De Fermat: Jurnal Pendidikan Matematika, 2(1), 4656.

Herlina. (2015). Pengaruh Pendekatan Aptitude Treatment Interaction (ATI) terhadap Pemahaman Konsep Matematika Siswa Kelas VIII SMP Negeri 25 Pekanbaru. Primary, 4(1), 79-86.

Karwono, \& Mularsih, H. (2017). Belajar dan Pembelajaran. Jakarta: Rajawali Pers.

Nanang, S., \& Damayanti, R. (2016). Analisis Kemampuan Komunikasi Matematis Siswa Lamban Belajar dalam Menyelesaikan Soal Bangun Datar. Aljabar, 7(No 1).

Panjaitan, M. R. (2013). Pengaruh Model Inkuiri terhadap Hasil Belajar Matematika Ditinjau dari Kemandirian Belajar Siswa di SMP N Salatiga. Jurnal Ilmiah
UKWS, Salatiga.

Pratiwi, D. D. (2016). Pembelajaran learning cycle $5 \mathrm{E}$ berbantuan geogebra terhadap kemampuan pemahaman konsep matematis. AlJabar: Jurnal Pendidikan Matematika, 7(2), 191-202.

Putra, R. W. Y. (2015). Perkembangan Konflik Kognitif untuk Meningkatkan Kemampuan Komunikasi Matematis Siswa Berdasarkan Kategori Pengetahuan Awal Matematis. Aljabar: Jurnal Pendidikan Matematika, 6(2),

Ruseffendi. (1979). Pengajaran Matematika Modern untuk Orang Tua Murid. Bandung: Tarsito.

Sugiyono. (2015). Metode Penelitian Pendidikan Kuantitatif, Kualitatif dan $R \& D$. Bandung: Alfabeta. 